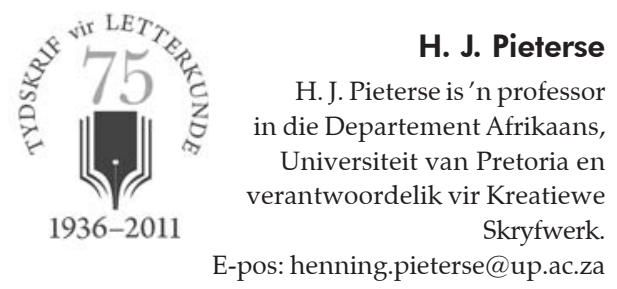

\title{
'n Kort rit in 'n vinnige voertuig
}

In 1986 het Piet Roodt en Elize Botha my genader om deel van Tydskrif vir Letterkunde se skakelredaksie te word. My hooftaak was om ingestuurde poësie te keur en later te help met die saamstel van die tydskrif. Een hoogtepunt was die saamstel van'n gerf geleentheidsverse ter nagedagtenis aan Stephen le Roux (Etienne Leroux, 1990). Teen die einde van die tagtigerjare het ek en Piet die meeste van die werk gedoen; prof. Elize kondig einde 1992 aan dat sy uittree as redakteur.

In my redaksionele kommentaar van vroeg 1993 het ek genoem dat ek Tydskrif op'n hoogtepunt oorgeneem het: die sirkulasiesyfers was in die duisende en die finansiële steun van die Afrikaanse Persfonds groot. Ek het geweet daar was'n "geskiedenis" met onder meer enkele van die Sestigers, maar ek het doelbewus voortgegaan om, in ' $n$ tyd waarin verskeie faksies' $n$ mens wou dwing om links, regs of watter kant ook al kant te kies, 'n neutrale redaksionele beleid te handhaaf en aan almal, ongeag ideologiese voorkeur, plek te gee in die blad, mits die bydraes uiteraard van' $n$ sekere gehalte was. Soos prof. Elize, het ek eenvoudig geglo in 'n diens aan die literatuur in die breë by wyse van kreatiewe tekste, resensies, artikels en bylaes oor voorgeskrewe tekste vir skole. Met die eerste uitgawe wat ek hanteer het, was ek baie gelukkig om briewe van Peter Blum aan Barend Toerien te kon plaas. (Barend se gesensureerde gedeeltes het ek ongedaan gemaak.)

Jaarliks was daar' $n$ vergadering met die verteenwoordigers van die Persfonds, mnr. Jan Victor (wat Eugène Marais geken het in 1935!) en mnr. J. J. Brits aan huis van prof. Elize. Hierdie geleenthede het redelik formeel begin, maar op'n goeie tydstip sou prof. Elize drankies aanbied en dan het die prosedures veel gemakliker verloop.

Die redaksionele medewerkers in 1993 was Piet Roodt, prof. Elize, Nico Snyman en Elsa Nolte. Die bestaande skakelredaksie was J. J. Brits, W. A. de Klerk, Marcel Janssens (Katholieke Universiteit, Leuven, België), Eben Meiring, P. J. Nienaber en Rika Cilliers. By hierdie name het ek onder meer Joan Hambidge, Tom Gouws, Zander Strachan en Charles Malan gevoeg.

Digters en skrywers wat gereeld in Tydskrif gepubliseer het in daardie tyd, sluit in Joan Hambidge, Lina Spies, Ilse van Staden, Christo van Staden (Johannes van Jerusalem), Leon de Kock, Sarina Dönges, Cas Vos, Charl-Pierre Naudé, Bernard Odendaal, Stephan Bouwer, Lucas Malan, Marius Crous, en later jonger digters wat 
in Nuwe Stemme sou publiseer: Toast Coetzer, Melt Myburgh, Jo Prins en Tertius Kapp, om enkeles te noem. Die meeste van hulle het intussen reeds gedebuteer met solobundels. Nuwe kortverhaalskrywers soos Anna Kemp, Johann de Lange en Paul Bosman het ook debuutverhale in Tydskrif gepubliseer. Koekie Ziervogel sou eenmalig herleef in Tydskrif.

Die eerste drie jaar kon ek en Piet—my regterhand oor baie jare—vier nommers per jaar publiseer. Die politieke bevryding van 1994 was nie so gunstig vir die Afrikaanse boek nie. Die voorgeskrewe mark het met $70 \%$ geval en Tydskrif was nie uitgesluit van hierdie lot nie.

Ek onthou 1996 om veral twee redes: jare lank is Tydskrif aangebied as "orgaan" van die Afrikaanse Skrywerskring; ek het hierdie gelade term vervang met "mondstuk" (die Afrikaanse Skrywerskring het uiteindelik spoorloos verdwyn; ek het nog ' $n$ stapel brons-gedenkplate van die Skrywerskring, bedoel as grafstene, in my kantoor by Unisa gehad). Gedurende daardie jaar het die Afrikaanse Persfonds, sonder verskaffing van enige redes, hul borgskap aan Tydskrif onttrek, wat ons in'n tydelike krisis gedompel het. Hierdie kwessie het ek in redaksionele kommentaar aangespreek en genoem dat nóg ek, nóg prof. Elize enige reaksie gehad het op telefoonboodskappe, fakse, telegramme en e-posse aan die Persfonds. Nasionale Pers het tot ons redding gekom en, deur bladgeld te hef en met'n ruim skenking van Marcel Janssens van die Katholieke Universiteit Leuven, kon ons weer op die been kom.

In 1996 en 1997 kon ek nog drie uitgawes per jaar aflewer, maar in 1999, 2000 en 2001 slegs twee gekombineerde uitgawes per jaar. Die geweldige afname in skoolinskrywings, intekenare, fondse oor die algemeen, groterwordende kompetisie met die internet en tydsbeperkings, was van die redes vir die vermindering in uitgawes.

In die laat-negentigerjare is ek via'n skrywe van die Departement van Onderwyssonder enige opgaaf van redes-ingelig dat Tydskrif nie meer op die lys van geakkrediteerde tydskrifte sal verskyn nie. Die daaropvolgende stryd en sirkus kan op sy beste as "Kafkaesk" beskryf word-jy kan Die verhoor en Die kasteel van Kafka lees, of jy kan probeer om rasionele argumente met die betrokke staatsdepartment te voer. Ek beveel die lees van hierdie boeke aan. Gelukkig is Tydskrif se status as geakkrediteerde tydskrif weer herstel.

In 2002 het daar geen uitgawe van Tydskrif verskyn nie. Die redes daarvoor was finansiële oorwegings en die feit dat dit heeltyd basies net ek en Piet was wat alles moes hanteer-keuring, saamstel, finale proeflees, ens. Ek gaan nie'n apologia pro vita mea hier probeer gee nie. As ek reg onthou, was ek teen die einde van 2002, na 24 uitgawes van die blad, redelik op moedverloor se vlakte en op die punt om die blad eiehandig te sluit. Gelukkig het Piet Roodt—-tot sy ewige eer-besluit hy het te veel tyd in hierdie projek gesteek om dit net te laat doodloop en hy het Hein Willemse oortuig om die blad oor te neem as redakteur. Hein het baie vinnig'n nuwe baadjie vir die tydskrif aangetrek_' $n$ meer inklusiewe blad vir Afrikaletterkunde wat hy met 
sy uitgebreide netwerk in Afrika onmiddellik ver oor die grense van slegs Afrikaans kon laat gedy.

Soos ek, het Hein al gesien dat jy nooit almal gelukkig kan hou nie. Ek onthou laatnagoproepe van lesers wat ongelukkig was oor politieke kwessies, of oor stukke wat as pornografies of onwelvoeglik beskou is, en die deurlopende hantering van skrywersego's. Dis'n eensame en ondankbare werk en by nabetragting wens ek dat ek Hein se ondersteuningskorps kon gehad het. Dit is uiteindelik wel ook dankbare en uiters leersame werk: die ontdekking van nuwe skrywers, plaaslik en oorsee, vlymskerp artikels van Henriette Roos, Rialette Wiehahn, Etienne van Heerden, André P. Brink, Joan Hambidge, Elsa Nolte, Louise Viljoen, Ena Jansen, Helize van Vuuren, Wilfried Jonckheere, en, later, Willie Burger en Andries Visagie, om enkeles te noem.

Tien jaar destyds is maar'n oogwink nou. Tyd rek en krimp vreemd binne die voertuig van die letterkunde. Ek is prof. Elize en Piet dankbaar vir die geleentheid om as redakteur te kon optree.

Baie geluk aan Hein met die uitstekende werk wat hy ook al byna tien jaar lank doen en alle voorspoed vir die toekoms.

\section{Erkenning}

Hierdie rede is gelewer by die herdenking van die 75ste bestaansjaar van Tydskrif vir Letterkunde (1951-) en sy direkte voorganger Die Jaarboek van die Afrikaanse Skrywerskring (1936-50) op 8 September 2011 in die Merensky-biblioteek, Universiteit van Pretoria. Die geleentheid is onder meer gevier met 'n uitstalling van Tydskrif-memorabilia onder die kuratorskap van Adrienne Warricker. 